\title{
Differential response of I VP, parthenogenetic and nuclear transfer derived bovine embryos upon environmental heat stress-implications for expression of autosomal and $X$-linked genes
}

\author{
MA Hashem ${ }^{1,2} *$, MM Hossain ${ }^{1}$, A Mohammadi-Sangcheshmeh ${ }^{2}$, U Cinar $^{2}$, F Rings $^{2}, \mathrm{~K}$ \\ Schellander $^{2}$, D Tesfaye ${ }^{2}$, M Hoelker $^{2}$ \\ ${ }^{1}$ Department of Animal Science, Bangladesh Agricultural University, Mymensingh 2202, Bangladesh; ${ }^{2}$ Institute \\ of Animal Science, Endenicher Allee 15, 53115, University of Bonn, Germany
}

\begin{abstract}
The present study was conducted to examine the metabolic activities and expression differences of Xlinked and autosomal genes upon exposure to heat stress using different types of bovine embryos. Embryos from in vitro fertilized (IVF), parthenogenetic (PA) and nuclear transfer (NT) were given heat treatment at morula stages at $40^{\circ} \mathrm{C}$ for $6 \mathrm{hrs}$. Treated embryos were studied for metabolic activities by quantification of G6PD-activity through Brilliant Cresyl Blue (BCB) staining and were used for X-linked and autosomal gene expression studies. Quantification of G6PD, PGK1, XIST as sex linked and SOX, BAX, OCT4, HSP70.1 as autosomal genes and GAPDH (endogenous control) mRNAs in each cDNA sample from heat treated and untreated embryos were assessed by quantitative PCR. Results of the present study indicate sexually dimorphic expression of selected X-linked and autosomal genes upon exposure to heat stress at morula stage in IVF, PA and NT embryos. Moreover, our study showed that female IVP derived embryos show highly decreased levels of XIST after heat shock. That could be one of the reasons for reduced in vitro developmental competence of female bovine embryos since XIST is the responsible gene for $\mathrm{X}$-chromosome inactivation. Any disturbance would result in dysregulation of all $\mathrm{X}$ Chromosomal encoded genes.
\end{abstract}

Key words: Gene expression, heat stress, nuclear transfer, sex difference

Bangladesh Animal Husbandry Association. All rights reserved.

Bang. J. Anim. Sci. 2013. 42 (1): 1-10

\section{Introduction}

Initiation of $\mathrm{X}$-chromosome inactivation and equal expression of X-linked genes such as glucose-6phosphate dehydrogenase (G6PD) and phosphoglycerate kinase (PGK) in females and males are critically dependent on the expression of the X-inactivate specific transcript (Lyon 1961, Wrenzycki et al. 2002, Wutz and Gribnau 2007). There are differences on the expression of sexlinked and autosomal genes between male and female embryos (Perez-Crespo et al. 2005) and between different stages of embryo as well (Wrenzycki et al. 2002). In vitro produced male embryos show a higher metabolic rate and grow faster than female embryos and total glucose metabolism is twice as high in male compared to female embryos. On the contrary, the activity of the pentose phosphate pathway (PPP) is four times greater in female than in male blastocysts (Tiffin et al. 1991). It has been reported that micromanipulated male human embryos grow faster than females (Dumoulin et al. 2005). Differences in metabolism and growth rates between sexes may therefore be attributable to the unbalanced expression of X-linked during some stages of the early preimplantation development, where both $\mathrm{X}$ chromosomes may be active (Epstein et al. 1978, Mak et al. 2004, Okamoto et al. 2004). The X-linked gene G6PD has been considered as one of the candidates for involvement in sex differences (Rieger 1992). The important role of this enzyme is to detoxify oxygen free radicals (Peippo and Bredbacka 1995). Similarly, PGK is a key enzyme in glycolysis, which is encoded from the $X$ chromosome (Wrenzycki et al. 2002). G6PD is involved in glucose metabolism through the PPP and oxygen radicals generated under high oxygen tension are diminished by active G6PD during embryo culture (Tiffin et al. 1991, Olson and Seidel 2000). Brilliant cresyl blue (BCB) is an electron acceptor that can be used to semiquantify the level of G6PD activity of live embryos by modification of a visual color (Williams 1986, Tian et al. 1998).

X-linked genes expressed from $\mathrm{X}$-chromosomes 
are associated with reactive oxygen species (ROS) and its activity is affected by heat stress. Heat stress increases $\mathrm{H}_{2} \mathrm{O}_{2}$ concentration (Yang et al. 1998, Ozawa et al. 2002, Sakatani et al. 2004), apoptosis (Arechiga et al. 1995, Kochhar et al. 2003) and altered gene expressions (Edwards and Hansen 1996, Sonna et al. 2002, Pfister-Genskow et al. 2005, Camargo et al. 2007) in different species of embryos and cells. Now-a-days Holstein breeds are being used for Al purposes in tropical countries for cross breeding. In Holstein cows, heat stress seems to decrease oocyte competence and the fertilization rate resulting in reduced embryo development leading to poor fertility during warmer climate (AlKatanani et al. 2002, Sartori et al. 2002). This susceptibility to heat stress makes European dairy breeds unpopular in tropical and subtropical countries where special care and housing are needed to reduce the effects of heat on fertility and milk yield. Identification of sex-linked genes and sex-related energy production pathway involving the heat stress response could be helpful for the evaluation, selection and regulation of preimplantation embryo in relation to sex of interest. The objective of the present study was to examine the differences in expression of $X$ linked and selected autosomal genes during heat stress at morula stages using different types of presexed bovine embryos. The metabolic differences were also studied between embryos by G6PDH- activity.

\section{Materials and Methods}

\section{Oocyte Recovery and In Vitro Maturation}

Bovine ovaries were obtained from a local slaughterhouse and transported to the laboratory within 2-4 $\mathrm{h}$ after slaughter in a thermo flask containing $0.9 \%$ saline. The cumulus oocyte complexes (COCs) were aspirated from follicles (2-8 $\mathrm{mm}$ in diameter) with an 18-gauge needle and COCs with multiple layers of cumulus cells were selected for in vitro maturation. The selected oocytes were washed in modified Parker medium (MPM) supplemented with $15 \%$ oestrus cow serum (OCS), $0.5 \mathrm{mM}$ L-glutamine, $0.2 \mathrm{mM}$ pyruvate, $50 \mu \mathrm{g} / \mathrm{ml}$ gentamycin sulphate and 10 $\mu \mathrm{l} / \mathrm{ml}$ FSH (Folltropin, Vetrepharm, Canada) before being set into culture. The COCs were cultured in groups of 50 in $400 \mu$ of MPM under mineral oil in four-well dishes (Nunc, Roskilde, Denmark). Maturation was performed for $24 \mathrm{~h}$ at $39{ }^{\circ} \mathrm{C}$ under a humidified atmosphere of $5 \% \mathrm{CO}_{2}$ in air.

\section{Generation of Nuclear Transfer-Derived Embryos}

Eighteen to $20 \mathrm{~h}$ (it is written as $24 \mathrm{~h}$ above) after the onset of maturation, the adhering cumulus cells were completely removed by vortexing COCs in $0.1 \%$ hyaluronidase (Sigma) in Ca- and Mg-free PBS for 2 min. Matured oocytes were selected by the presence of a visible extruded first polar body and randomly used for activation or nuclear transfer (NT). Adult fibroblast cell lines were established from ear skin samples of an adult bull. Ear skin samples were cut into small pieces and dispersed in $0.1 \%$ trypsin. Explants were maintained in Dulbecco's modified Eagle medium-F12 and trypsinized at $90 \%$ confluency. The harvested cells were reconstituted at a concentration of $1 \times 10^{6}$ cells $/ \mathrm{ml}$ and then either frozen in $10 \%$ dimethyl sulfoxide or returned to culture following standard procedure. The fibroblasts used for NT in these experiments were from passages 2-4 and were induced to enter a period of quiescence (presumptive G0) by serum starvation for 7 days ( $0.5 \%$ fetal calf serum).

Oocytes were enucleated by aspirating the first polar body and the MII plate. Oocytes were stained in TCM-air (air is not clear to me) containing $5 \mu \mathrm{g} / \mathrm{ml}$ Hoechst 33342 and $7.5 \mu \mathrm{g} / \mathrm{ml}$ cytochalasin B. Enucleation was confirmed by brief exposure of the karyoplast to ultraviolet light. Immediately before injection, a suspension of the donor cells was prepared by standard trypsinization. The cells were pelleted and resuspended in TCM-air and remained in this medium until injection. A single cell was sucked into a $30-\mu \mathrm{m}$ (outer diameter) pipette and carefully inserted into the perivitelline space of the enucleated oocytes. Reconstructed oocytess were electrically fused at $26 \mathrm{~h}$ after onset of maturation by $0.285 \mathrm{M}$ mannitol containing 0.1 $\mathrm{mM} \mathrm{MgSO} 4$ and $0.05 \%$ BSA with 1 or 2 DC pulses of $0.7 \mathrm{kV}$ for $30 \mu \mathrm{sec}$ each generated by an electrofusion machine (CFA 400; Kruess, Hamburg, Germany). Fusion was assessed 30 min later by light microscopy.

\section{Activation and Culture of Reconstructed NT Embryos}

At $27 \mathrm{~h}$ after onset of maturation, the reconstructed embryos were chemically activated by incubation in $5 \mu \mathrm{M}$ ionomycin (Sigma) in TCM 199 for $5 \mathrm{~min}$ followed by a 3- to 4-h incubation in $2 \mathrm{mM}$ 6-dimethylaminopurine (6-DMAP; Sigma) 


\section{Gene expression in bovine embryos under heat stress}

in TCM 199 at $37^{\circ} \mathrm{C}$. After washing 3 times, the embryos were cultured in Charles Rosenkrans 1 (CR1) culture medium supplemented with $10 \%$ OCS, $20 \mu \mathrm{l} / \mathrm{ml}$ Eagle's basal medium (BME) and $10 \mu \mathrm{l} / \mathrm{ml}$ Minimum essential medium (MEM, Gibco $B R L)$. Cleavage rate was assessed $48 \mathrm{~h}$ after insemination (is it IVF embryo?), while morula and blastocyst rates were determined at days 5 and 6-8 after fusion, respectively.

\section{In Vitro Fertilization and Embryo Culture}

Two frozen semen straws were thawed at a temperature of $39{ }^{\circ} \mathrm{C}$ for $8 \mathrm{sec}$ in a water bath, and separated by means of the 'swim up' technique (Parrish et al. 1988) (This reference is missed in list). The matured oocytes in groups of 50 were transferred to fertilization medium and inseminated with spermatozoa at a concentration of at $1 \times 10^{6}$ cells $/ \mathrm{ml}$. Fertilization was initiated during co-incubation of spermatozoa and matured oocytes for $20 \mathrm{hr}$ under the same condition as used for maturation. Cumulus free zygotes were washed and transferred to CRlaa culture media supplemented with essential and nonessential amino acids. Further culture in culture medium was performed in the same incubator and under the same conditions as used for maturation and fertilization. Oocytes and embryos were collected from the culture at specific time points after maturation or fertilisation. In order to assess the effect of heat stress on morula and blastocyst stage NT embryos, embryos were collected at specific times after treatment for mRNA analysis. In both experiments, NT embryos were cultured in vitro until day 8 blastocyst stage to assess development. In both experiments embryos were given heat stress at morula stages at $40^{\circ} \mathrm{C}$ for 6 hours. The resulting blastocysts from each treatment group were used for transcription analysis. BCB staining was done before freezing the samples. Until RNA isolation, all frozen embryos were stored at $-80^{\circ} \mathrm{C}$.

\section{Production of bovine parthenogenetic embryos}

The denuded IVM oocytes with first polar body were selected for chemical activation. The activation of the oocytes was carried out by pretreating the oocytes with TCM air containing $5 \mu \mathrm{M}$ Ionomycin at room temperature for $5 \mathrm{~min}$, followed by culture in CRlaa medium supplemented with $2 \mathrm{mM}$ 6-DMAP for $4 \mathrm{~h}$. Subsequent culture was performed in CRlaa medium.

\section{Brilliant Cresyl Blue (BCB) Staining of COCs}

The level of G6PD in individual embryos was assessed by a modification of a visual calorimetric assay for G6PD in blood. This test measures the reduction of the vital blue stain, brilliant cresyl blue (BCB), to a colourless compound. The procedure of $B C B$ staining was done as described in previous studies (Alm et al. 2005, Bhojwani et al. 2007). Briefly, heat treated and untreated embryos were subjected to $13 \mu \mathrm{M}$ BCB (B-5388, Sigma-Alderich, Taufenkirchen, Germany) diluted in D-PBS for $10 \mathrm{~min}$ at $38.5^{\circ} \mathrm{C}$ in humidified air atmosphere. After washing, the stained embryos were examined under stereomicroscope and categorised into two groups according to their cytoplasm colouration: oocytes with any degree of blue colouration in the cytoplasm ( $B C B+$, category 1 i.e., low G6PD level) and oocytes without visual blue colouration (BCB-, category 2, i.e., high G6PD level). Category 1 embryos were considered to have low G6PD activity and category 2 embryos were considered to have high G6PD activity. From each group the individual embryo were snap frozen and stored in $-80^{\circ} \mathrm{C}$. Embryo categorization was carried out by one person. All reagents were from Sigma Chemical Company, St. Louis, MC, U.S.A unless otherwise stated.

\section{Total RNA I solation and cDNA Synthesis for Analysis of Target Genes}

A total of three to six replications each containing single embryo were used for total RNA isolation using PicoPureTM RNA Isolation kit ((MDC, USA) as described in user guide. The RNA was then reverse transcribed to CDNA using superscript II reverse transcriptase (Invitrogen, Carlsbad, CA). Briefly, $11 \mu$ l of total RNA from each sample, 0.5 $\mu \mathrm{l}$ of random primer and $0.5 \mu$ of oligo $(\mathrm{dT})_{23}$ were mixed and incubated at $70^{\circ} \mathrm{C}$ for $3 \mathrm{~min}$ and then the samples were kept on ice for $2 \mathrm{~min}$. The RNA samples were reverse transcribed in a $20 \mu \mathrm{l}$ reaction volume containing $4 \mu \mathrm{l} 5$ times first strand buffer, $2 \mu \mathrm{l}$ DT, $1 \mu \mathrm{l}$ dNTP, $0.3 \mu \mathrm{l}$ RNasin and $0.7 \mu$ l of RT enzyme (Superscript II). The CDNA was then used for the quantitative real time PCR to quantify the target genes (G6PD, PGK1, XIST, Cow Specific, Y-Chromosome specific, SOX, BAX, OCT4, HSP70.1 and GAPDH) using sequence specific primers. 
Hashem et al. (2013) Bang. J. Anim. Sci. 42 (1): 1 - 10

Table 1. List of Primers Used for qRT-PCR Quantification of Target Genes with Corresponding Sequences, Product Length and Annealing Temperature

\begin{tabular}{|c|c|c|c|}
\hline Genes & $\begin{array}{l}\text { Primer sequences }\left(3^{\prime}-5^{\prime}\right) \\
\text { (F: Forward, R: Reverse) }\end{array}$ & $\mathrm{T}_{\mathrm{A}}\left({ }^{\circ} \mathrm{C}\right)$ & $\begin{array}{l}\text { Amplicon } \\
\text { size (bp) }\end{array}$ \\
\hline \multirow[t]{2}{*}{ G6PD } & F-CGCCTCAACAGCCACATAAAT & \multirow{2}{*}{57} & \multirow{2}{*}{161} \\
\hline & R-AACGGCTTCTCCACGATGAT & & \\
\hline \multirow[t]{2}{*}{ PGK1 } & F-GAGGATCAAGGCTGCTGTTC & \multirow{2}{*}{60} & \multirow{2}{*}{210} \\
\hline & R-CAAGCCTTCTCCACTTCTGG & & \\
\hline \multirow[t]{2}{*}{ Xist } & F-TGGACAGCATCCAAAGGACA & \multirow{2}{*}{60} & \multirow{2}{*}{167} \\
\hline & R-TGCCCCATCTCCACCTIT & & \\
\hline Y-Chr. & F-GCAACCCGATGCATGTAGAGA & \multirow{2}{*}{60} & \multirow{2}{*}{172} \\
\hline Specific & TTATTGTGGCCCAGGCTTGT & & \\
\hline Cow & F-AGGTCGCGAGATTGGTCGCTAGGTCATGCA & \multirow{2}{*}{57} & \multirow{2}{*}{300} \\
\hline Specific & R-AAGACCTCGAGAGACCCTCTTCAACACGT & & \\
\hline \multirow[t]{2}{*}{ Oct4 } & F-GTTITGAGGCTTTGCAGCTC & \multirow{2}{*}{57} & \multirow{2}{*}{182} \\
\hline & R-CTCCAGGTTGCCTCTCACTC & & \\
\hline \multirow[t]{2}{*}{ Bax } & F-TGCAGAGGATGATCGCAGCTGTG & \multirow{2}{*}{57} & \multirow{2}{*}{198} \\
\hline & R-CCAATGTCCAGCCCATCATGGTC & & \\
\hline \multirow[t]{2}{*}{ Sox } & F-CCTGAGGCCAGGAGTTCAAGACC & \multirow{2}{*}{60} & \multirow{2}{*}{200} \\
\hline & R-GCAATAGTGTGATCTCGGCTCACTG & & \\
\hline \multirow[t]{2}{*}{ HSP70.1 } & F-AACAAGATCACCATCACCAACG & \multirow{2}{*}{60} & \multirow{2}{*}{275} \\
\hline & R-TCC TTC TCC GCC AAG GTG TTG & & \\
\hline \multirow[t]{2}{*}{ GAPDH } & F-AAGGTCGGAGTGAACGGATTC & \multirow{2}{*}{60} & \multirow{2}{*}{170} \\
\hline & R-TTGACTGTGCCGTTGAACTTG & & \\
\hline
\end{tabular}

\section{Real-Time Quantitative PCR for Target Genes}

Quantification of G6PD, PGK1, XIST (as sex-linked genes), Cow Specific, Y-Chromosome specific (used for sex determination) SOX, BAX, OCT4, HSP70.1(as autosomal genes) and GAPDH (endogenous control) mRNAs in each cDNA samples from heat treated and untreated embryos were assessed by quantitative PCR. The ABI Prism 7000 apparatus (Applied Biosystems, Foster City, CA) was used to perform the quantitative analysis using iTaq SYBR Green Supermix with ROX (Bio-Rad, Hercules, CA). Quantification of all transcripts was done in comparison with GAPDH as an endogenous control. The primer sequences (Table 1) were designed for PCR amplification according to the bovine CDNA sequences using the software Primer3 (version 0.4). All primers were optimized and validated through PCR followed by sequencing. All PCRs were performed in a $20 \mu \mathrm{l}$ reaction volume containing $10 \mu \mathrm{l}$ iTaq SYBR Green; optimal levels of forward and reverse primers and $2 \mu \mathrm{l}$ of embryo cDNA samples. During each PCR reaction, samples from the same cDNA source were run in duplicate to control the reproducibility of the results. A universal thermal cycling parameter with initial denaturation step at $95^{\circ} \mathrm{C}$ for $3 \mathrm{~min}, 40$ cycles of PCR cycling at $95^{\circ} \mathrm{C}$ for $15 \mathrm{sec}$ and $60^{\circ} \mathrm{C}$ for $45 \mathrm{sec}$ was used to run the PCR. Finally, quantitative analysis was done using the comparative $\mathrm{CT}$ method [ABI Prism Sequence Detection System User Bulletin No. 2]. Negative controls were performed in which PCR grade water was substituted for CDNA or reverse transcriptase was omitted during the reverse transcription reaction.

\section{Experimental design}

IVF, PA and NT embryos were given heat treatment at $40^{\circ} \mathrm{C}$ at morula stages for $6 \mathrm{hrs}$. Embryos were cultured until days 8 after given heat treatment or without heat treatment. Metabolic activities of each embryo from IVF, PA and NT in heat treated and untreated groups were examined by G6PD activity through BCB staining as $B C B+$ and $B C B$ - replicated three times in each treatment. Sex linked (G6PD, XIST, PGK1) and autosomal (SOX, BAX, OCT4, HSP70.1) genes expressions were studied in heat treated and untreated of each embryo from IVF, PA and NT by qRT-PCR which was replicated four to six times irrespective of treatments. Both Cow Specific and Y-Chromosome specific genes were used for sex determination through real time PCR. In this case cDNA from single embryo was used.

\section{Statistical Analysis}

The data of all experiments were statistically analysed; differences of $\mathrm{P} \leq 0.05$ were considered to be significant. The data were expressed as 


\section{Gene expression in bovine embryos under heat stress}

means \pm S.E. M. The relative mRNA expression data were analysed using General Linear Model (GLM) of the Statistical Analysis System (SAS) software package version 9.1 (SAS Institute Inc., Cary, NC, USA). Differences in mean values were tested using ANOVA followed by Tukey's Multiple Comparison test.

\section{Results}

Correlation between G6PD activity measured by BCB staining and G6PD transcript abundance in IVF female, PA and NT male embryos

Transcript abundance for G6PD was higher in $\mathrm{BCB}$ - compared to $\mathrm{BCB}+$ embryos in case of IVF and NT derived embryos both for control embryos and heat treated embryos. In Contrast, abundance did not differ for parthenogenetic embryos (Figure 1). Considering the non treated control group, G6PD activity was significantly higher $(p<0.05)$ in IVF female and PA groups compared to NT male group. With respect to heat treated groups, only PA embryos within the BCB+ classified embryos showed significant $(p<0.05)$ differences compared to IVF female and NT male embryos.



Figure 1. G6PD activity after $B C B$ staining in IVF female, PA and NT male single embryo. (IVF: Single IVF female, PAE: Single parthenogenetic, NTM: Single cloned male embryo)

\section{Effect of heat stress on gene expression of female IVP embryos}

To evaluate the effect of heat stress on the transcription of sex linked genes G6PD, PGK1, XIST and autosomal genes SOX, BAX, Oct4 and HSP70.1 were measured transcript abundance in heat treated female IVP derived embryos in comparison to non treated controls. Transcripts of the sex linked genes G6PD and XIST were decreased abruptly in heat treated group compared to control $(P<0.05)$ (Figure 2). PGK1 expression was equal both in control and heat treated group $(p<0.05)$. In contrast autosomal gene transcripts of SOX, Oct4 and HSP70.1 were significantly upregulated in heat treated group compared to untreated controls $(p<0.05)$ while BAX was equally expressed in heat treated and untreated groups $(p>0.05)$.

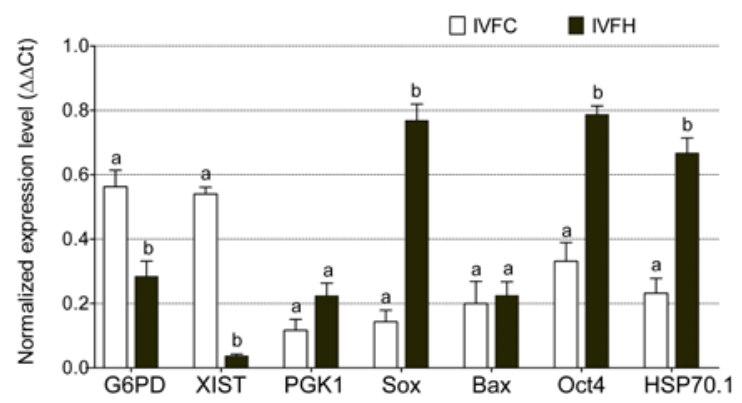

Figure 2. Sex-linked and autosomal gene expression in control and heat treated single female IVF embryo. (IVFC: Single IVF embryo without heat stress, IVFH: Single IVF embryo with heat stress)

\section{Effect of heat stress on gene expression of} parthenogenetic embryos

The effect of heat treatment on PA embryos on the expression of selected sex-linked and autosomal genes is shown in Figure 3 . Considering the X-linked genes G6PD and PGK1, no differences in transcript abundance became visible between heat treated and untreated PA embryos $(p>0.05)$. In Contrast, XIST was highly upregulated in heat treated group compared to control $(p>0.05)$. With respect to autosomal genes, Oct4 was significantly higher in heat treated group $(p<0.05)$, whereas sox was significantly downregulatd upon heat treatment. Transcripts of BAX and HSP70.1 were equal in expression both in heat treated and untreated groups.

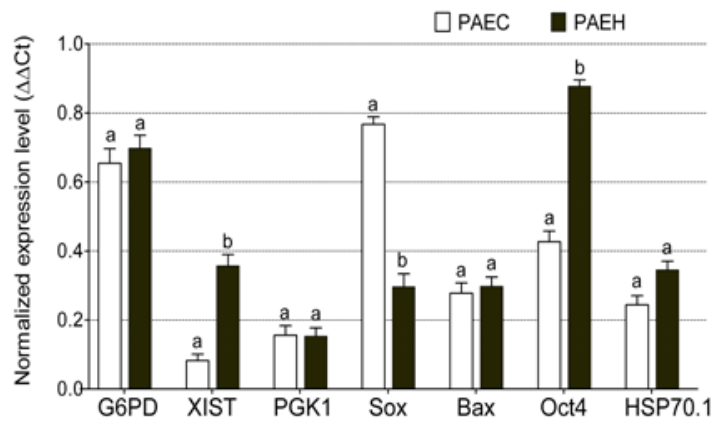

Figure 3. Sex-linked and autosomal gene expression in control and heat treated single parthenogenetic embryo. (PAEC: Single parthenogenetic embryo without heat stress, PAEH: Single parthenogenetic embryo with heat stress) 


\section{Effect of heat stress on gene expression of male NT derived embryos}

To examine the differential expressions of sexlinked and autosomal genes in pre-sexed embryos, male NT embryos were produced. Sexlinked and autosomal gene expression in male NT embryos after heat treatment is shown in Figure 4. Transcripts abundance of G6PD and XIST genes were similar for heat treated and untreated group $(p>0.05) \quad$ while PGK1 was significantly upregulated in heat treated groups $(p<0.05)$. All autosomal genes (SOX, BAX, Oct4 and HSP70.1) were significantly upregulated in heat treated NT embryos compared to control $(p<0.05)$.

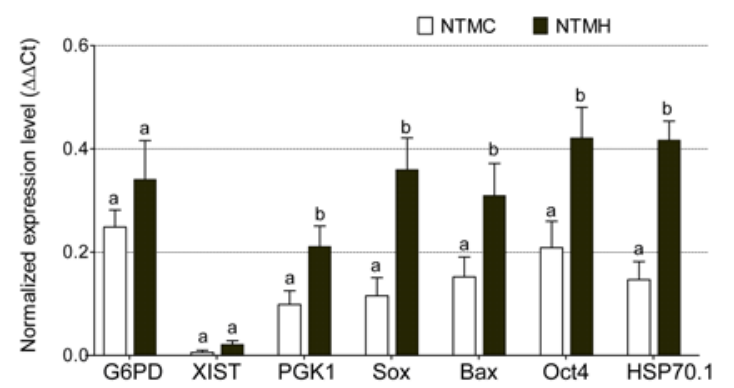

Figure 4. Sex-linked and autosomal gene expression in control and heat treated single NT male embryo. (NTMC: Single cloned male embryo without heat stress, NTMH: Single cloned male embryo with heat stress)

\section{Changes of gene expression in single embryos of different sources due to heat treatment}

The degree of expression changes of sex-linked and autosomal genes in different types of embryo are presented in Figure 5. The sex-linked gene G6PD was found to be more than 2 fold downregulated in heat treated female IVF embryos but upregulated in PA and NT embryo compared to their controls. XIST was significantly highly expressed in female IVF embryo, which shows about 14 fold down regulation in heat treated IVF embryos compared to their control. Whereas in PA and NT, it was more than 2 fold upregulated in heat treated group compared to their control. However, PGK1 was found to be expressed highly by about 2 fold either in heat treated female IVF or male NT embryo but downregulated in heat treated PA embryos compared to the corresponding control embryos. In case of SOX, the patterns of expression changes due to heat treatment were more similar to that of PGK1 but degree was more profound. For the other autosomal genes (BAX, OCT4 and HSP70.1), heat treated embryo of any sources exhibit about 2 fold upregulation compared to their corresponding control embryos without heat treatment.

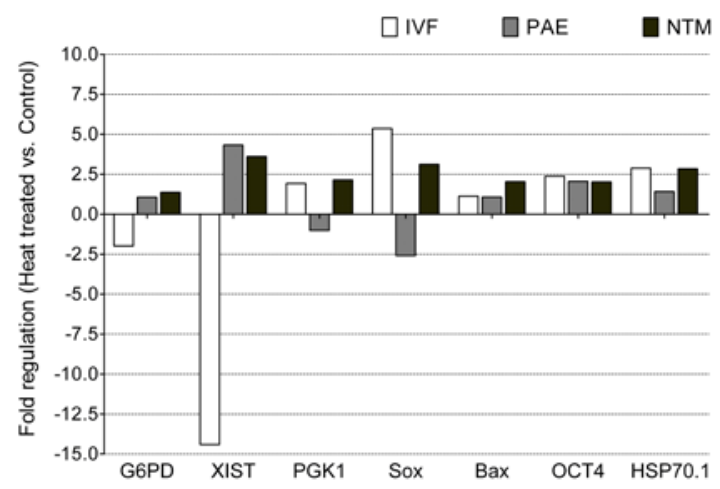

Figure 5. Fold change differences in expression of genes in between the heat treated IVF female, PA and NT male single embryo and corresponding control embryo.

\section{Discussion}

In vitro embryo production (IVP) and cloning result in aberrant expression patterns of developmentally important genes (Niemann and Wrenzycki 2000). Gene expression patterns in preimplantation bovine embryos are altered by in vitro culture conditions and the NT protocol (Wrenzycki et al. 1999, Wrenzycki et al. 2001). IVP and NT lead to alterations in dosage compensation of $\mathrm{X}$-linked gene expression, which in turn could result in deviations from the normal sex ratio (Wrenzycki et al. 2002). Culture of embryos at high temperatures has been reported to reduce embryonic development (Edwards and Hansen 1996, Edwards et al. 2001). Heat stress during oocyte maturation and/or fertilization adversely has been shown to affect oocyte maturation and fertilization rates leading to retarded further embryonic development (Sugiyama et al. 2007). It has been shown that bovine oocytes fertilized at $41^{\circ} \mathrm{C}$ for $8 \mathrm{~h}$ had lower cleavage rates than did oocytes fertilized at $38.5^{\circ} \mathrm{C}$ in vitro; however, incubation at $40^{\circ} \mathrm{C}$ during IVF had no effect on cleavage rate and tended to increase the rate of oocytes forming blastocysts compared with oocytes fertilized at $38.5^{\circ} \mathrm{C}$ (Rivera and Hansen 2001). The deleterious effect of bovine embryos at $41^{\circ} \mathrm{C}$ was not dependent upon oxygen content or the gas mixture used for culture ( $5 \%$ versus $20.95 \% \mathrm{O}_{2}$ ) and it indicates that the deleterious effects of heat shock did not depend upon a high $\mathrm{O}_{2}$ environment (Rivera and Hansen 2001). The Present experiment has been conducted to explore the metabolic activities and expression 


\section{Gene expression in bovine embryos under heat stress}

level of selected sex-linked and autosomal genes with or without heat treatment in bovine female IVF, PA and male NT embryos.

In the first experiment, we examined metabolic activities by measuring G6PD activity using BCB staining in heat treated and control groups. Expression of G6PD in PA embryos was higher compared to female IVP embryos. That could be related to imprinting effects. In case of parthenogenetic embryos both $\mathrm{X}$-Chromosomes are derived from the mother whereas in female IVP derived embryos one $\mathrm{X}$-Chromosome is derived by the father. Classification of embryos into $\mathrm{BCB}+$ and $\mathrm{BCB}$ - correlated with transcript abundance of G6PD in case of IVF and NT derived embryos. In contrast equal expression of G6PD was obtained in $\mathrm{BCB}+$ and $\mathrm{BCB}$ - embryos. However it has taken into account that classification according to BCB test is based on activity of the G6PD enzyme whereas gene expression is due to transcript abundance which could be subsequently affected by different modification resulting alteration of protein expression. Result of the present study shows that female embryos have got higher G6PD activity than male embryo. This finding is in agreement with the findings of other authors (Tiffin et al. 1991; Gutierrez-Adan et al. 2000). One possible explanation of the mechanism is that female embryos at the blastocyst stage possess two active $X$ chromosomes in the ICM and could therefore be less susceptible to metabolic imbalance as a result of gene dosage as reported previously (Gutierrez-Adan et al. 2000; Wrenzycki et al. 2002). Genes that are located on the X-chromosome, such as G6PD, the gatekeeper for the pentose-phosphate pathway are strongly expressed in female than male morulae and blastocysts (Taylor et al. 2001, I wata et al. 2002). Subsequently, it has been reported that the amount of mRNA of G6PD is more in female blastocysts than in male (Gutierrez-Adan et al. 2000), because of higher glucose metabolism through PPP in female blastocysts compared to that in male embryos (Tiffin et al. 1991). After heat treatment, expression pattern of G6PD activity decreased in IVF female embryos whereas, upon heat treatment, no differences in the control group were observed in PA and male NT embryos (Figure 5).

The relative expression of XIST was higher in female IVF, moderate in PA embryo and very low or undetectable in male NT embryos. However, upon heat stress, the changes of its expression show very similar pattern to that observed in case of G6PD (Figure 5). The ectopic XIST expression has been observed to adversely affect gene expression in NT embryos in a genome-wide manner through complex gene networks connecting autosomal genes and $\mathrm{X}$-linked genes in different sexes that direct embryonic development (Inoue et al. 2010). In that context, downregulation of XIST would prevent $X$ chromosome inactivation. That could be added to the phenomenon that female IVP embryos develop with lower probability to the blastocyst stage in vitro compared to male IVP embryos. In addition, during heat stress condition more male calves were obtained from in vitro cultured and transferred embryos (either single or double) compared to the female calves (Franco et al. 2006).

Another sex linked gene, the PGK1 is a key enzyme in glycolysis which helps actively utilization of glycolytic substrates to meet the energy requirements at the early stage. An increase in such utilization has been reported as a mean to meet the growing energy demands of $\mathrm{Na}+\mathrm{K}+$ ATPase during the formation and maintenance of the blastocoels (Rieger et al. 1992) and reported to be essential for hatching of the bovine blastocyst (Renard et al. 1980). Higher glucose utilization has also been directly correlated with greater blastocyst viability and better developmental potential in vitro in Day 10 cattle embryos (Renard et al. 1980). Very little differences in expression of PGK1 in either any types of embryo tested were observed. However, similar to G6PD, PGK1 expression was found to be induced in male NT embryo upon heat stress but no change was observed in case of female IVF and PA embryos (Figure 5). Changes in expression of PGK seem to reflect the metabolic differences by the bovine embryos of different sexes.

Most of the autosomal genes studied in this experiment, were found to be upregulated upon exposure to heat stress condition in different types of embryos (except Sox in PA embryos). These autosomal genes were found to be about 2 fold upregulated under heat stress condition. Stress agents have been reported to induce gene transcription prior to the major activation of the bovine genome (Edwards et al. 1997). As a stress sensitive peroxisomal enzyme, Sox plays an important role in glucose and lipid metabolism (Gutierrez-Adan et al. 2004). In the present study, higher abundance of Sox mRNA observed in IVP and NT embryos indicated that the embryo 
could respond against heat stressed condition. The Bax gene is a pro-apoptotic member of the $\mathrm{Bcl}-2$ protein family which promotes apoptosis by competing with $\mathrm{Bcl}-2$ proper. Expression of Bax mRNA was found to be almost similar in any groups of embryos. However, in all three types of embryos, it shows upregulation of this gene compared to their corresponding control embryos. So, elevated expression of Bax could be one of the reasons for apoptosis of embryonic cells in the sub-optimal in vitro culture condition. Similarly, Oct- 4 is a transcription factor initially active in the oocyte and remains throughout the preimplantation period. Expression of this gene was found to be similar in IVF, PA and NT embryos. Interestingly, it is equally upregulated (about 2 fold) in each type of embryo under heat treatment compared to their corresponding control embryo without heat stress. The analysis of the expression pattern of Hsp 70.1, considering its relative higher importance in growth and development, could be potentially used as a biomarker for the study of the consequences of in vitro conditions on embryo quality (Oliveira et al. 2006). HSP70.1 protects cells against adverse effects of stress and was significantly higher in embryos cultured in hyperthermic conditions. This finding confirms that Hsp 70.1 is a sensitive indicator of embryonic stress in sub-optimal culture conditions (Wrenzycki et al. 1999). Result of the present study suggests that, the suboptimal IVC conditions especially heat stress induces expression of specific genes such as Sox, Bax, Oct4 and HSP70.1 in the embryos produced by different methods.

The Results of the present study show sexually dimorphic expression of selected X-linked and autosomal genes upon exposure heat stress at morula stage comparing in in-vitro produced, parthenogenetic and cloned bovine embryos. This finding relates to the activity of female IVF, PA and male NT embryos in gene expression to the heat and oxidative stress induced by the in vitro conditions and thereby could reflect the differential adaptive response by the embryos of different sources and sex. Altogether, high temperature alters the expression of sex linked and autosomal gene expression, which may lead to low embryonic development and this, could be linked to the low fertility of exotic cow in the tropical environment caused by summer heat stress. Most interestingly, female IVP embryos suspected to heat stress show highly decreased expression of XIST. That is may be one of the reasons for higher (higher is ok?) developmental rates of bovine embryos.

\section{Acknowledgement}

This research was funded by the Alexander von Humboldt Foundation.

\section{References}

Al-Katanani YM, Paula-Lopes FF, Hansen PJ (2002). Effect of season and exposure to heat stress on oocyte competence in Holstein cows. Journal of Dairy Science, 85: 390-396.

Alm H, Torner $\mathrm{H}$, Lohrke B, Viergutz $\mathrm{T}$, Ghoneim IM, Kanitz W (2005). Bovine blastocyst development rate in vitro is influenced by selection of oocytes by brillant cresyl blue staining before IVM as indicator for glucose -6-phosphate dehydrogenase activity. Theriogenology, 63: 2194-2205.

Arechiga CF, Ealy AD, Hansen PJ. (1995). Evidence that glutathione is involved in thermotolerance of preimplantation murine embryos. Biology of Reproduction, 52: 1296-1301.

Bhojwani S, Alm H, Torner H, Kanitz W, Poehland R (2007). Selection of developmentally competent oocytes through brilliant cresyl blue stain enhances blastocyst development rate after bovine nuclear transfer. Theriogenology, 67: 341-345.

Camargo LS, Viana JH, Ramos AA, Serapiao RV, de Sa WF, Ferreira AM, Guimaraes MF, do Vale Filho VR (2007). Developmental competence and expression of the Hsp 70.1 gene in oocytes obtained from Bos indicus and Bos taurus dairy cows in a tropical environment. Theriogenology, 68: 626-632.

Dumoulin JC, Derhaag JG, Bras M, Van Montfoort $A P$, Kester AD, Evers JL, Geraedts JP, Coonen E (2005). Growth rate of human preimplantation embryos is sex dependent after ICSI but not after IVF. Human Reproduction, 20: 484-491.

Edwards J L, Ealy AD, Monterroso VH, Hansen PJ. 1997. Ontogeny of temperature-regulated heat shock protein 70 synthesis in preimplantation bovine embryos. Molecular Reproduction and Development, 48: 25-33.

Edwards JL, King WA, Kawarsky SJ, Ealy AD (2001). Responsiveness of early embryos to environmental insults: Potential protective roles of HSP70 and glutathione. Theriogenology, 55: 209-223.

Edwards JL; Hansen PJ (1996). Elevated temperature increases heat shock protein 70 synthesis in bovine two-cell embryos and compromises function of maturing oocytes. Biology of Reproduction, 55: 341- 


\section{Gene expression in bovine embryos under heat stress}

346.

Epstein CJ, Smith S, Travis B, Tucker G (1978). Both $X$ chromosomes function before visible $X$-chromosome inactivation in female mouse embryos. Nature, 274: 500-503.

Franco $M$, Block J, J ousan FD, de Castro e Paula LA, Brad AM, Franco J M, Grisel F, Monson RL, Rutledge JJ, Hansen PJ (2006). Effect of transfer of one or two in vitro-produced embryos and post-transfer administration of gonadotropin releasing hormone on pregnancy rates of heat-stressed dairy cattle. Theriogenology, 66: 224-233.

Gutierrez-Adan A, Oter M, Martinez-Madrid B, Pintado B, De La Fuente J (2000). Differential expression of two genes located on the $X$ chromosome between male and female in vitro-produced bovine embryos at the blastocyst stage. Molecular Reproduction and Development, 55: 146-151.

Gutierrez-Adan A, Rizos D, Fair T, Moreira PN, Pintado B, De La Fuente J, Boland MP, Lonergan P (2004). Effect of speed of development on mRNA expression pattern in early bovine embryos cultured in vivo or in vitro. Molecular Reproduction and Development, 68: 441-448.

Inoue $\mathrm{K}$, Kohda $\mathrm{T}$, Sugimoto $\mathrm{M}$, Sado $\mathrm{T}$, Ogonuki N, Matoba S, Shiura H, I keda R, Mochida K, Fujii T, Sawai K, Otte AP, Tian XC, Yang $X$, Ishino F, Abe K, Ogura A (2010). Impeding Xist expression from the active $X$ chromosome improves mouse somatic cell nuclear transfer. Science, 330: 496-499.

I wata $\mathrm{H}$, Kimura $\mathrm{K}$, Hashimoto $\mathrm{S}$, Ohta $\mathrm{M}$, Tominaga K, Minami N (2002). Role of G6PD activity on sex ratio and developmental competence of bovine embryos under oxidative stress. Journal of Reproduction and Development, 48: 447453.

Kochhar HS, Kochhar KP, Basrur PK, King WA (2003). Influence of the duration of gamete interaction on cleavage, growth rate and sex distribution of in vitro produced bovine embryos. Animal Reproduction Science, 77: 33-49.

Lyon MF (1961). Gene action in the Xchromosome of the mouse (Mus musculus L.). Nature, 190: 372-373.

Mak W, Nesterova TB, de Napoles M, Appanah R, Yamanaka S, Otte AP, Brockdorff N (2004). Reactivation of the paternal $X$ chromosome in early mouse embryos. Science, 303: 666-669.

Niemann H, Wrenzycki C (2000). Alterations of expression of developmentally important genes in preimplantation bovine embryos by in vitro culture conditions: implications for subsequent development. Theriogenology, 53: 21-34.

Okamoto I, Otte AP, Allis CD, Reinberg D, Heard E (2004). Epigenetic dynamics of imprinted $X$ inactivation during early mouse development. Science, 303: 644-649.

Oliveira AT, Lopes RF, Rodrigues JL (2006). Gene expression and developmental competence of bovine embryos produced in vitro with different serum concentrations. Reproduction of Domestic Animals, 41: 129-136.

Olson SE, Seidel GE Jr (2000). Reduced oxygen tension and EDTA improve bovine zygote development in a chemically defined medium. J of Animal Science, 78: 152-157.

Ozawa M, Hirabayashi M, Kanai Y (2002). Developmental competence and oxidative state of mouse zygotes heat-stressed maternally or in vitro. Reproduction, 124: 683-689.

Peippo J, Bredbacka P (1995). Sex-related growth rate differences in mouse preimplantation embryos in vivo and in vitro. Molecular Reproduction and Development, 40: 56-61.

Perez-Crespo M, Ramirez MA, Fernandez-Gonzalez R, Rizos D, Lonergan P, Pintado B, Gutierrez-Adan A (2005). Differential sensitivity of male and female mouse embryos to oxidative induced heat-stress is mediated by glucose-6-phosphate dehydrogenase gene expression. Molecular Reproduction and Development, 72: 502-510.

Pfister-Genskow M, Myers C, Childs LA, Lacson JC, Patterson T, Betthauser JM, Goueleke PJ, Koppang RW, Lange G, Fisher $\mathrm{P}$, Watt SR, Forsberg EJ, Zheng $Y$, Leno $\mathrm{GH}$, Schultz RM, Liu B, Chetia C, Yang X, Hoeschele I, Eilertsen KJ (2005). Identification of differentially expressed genes in individual bovine preimplantation embryos produced by nuclear transfer: improper reprogramming of genes required for development. Biology of Reproduction, 72: 546-555.

Renard J P, Philippon A, Menezo Y (1980). In-vitro uptake of glucose by bovine blastocysts. J Journal of Reproduction and Fertility, 58: 161-164.

Rieger D (1992). Relationships between energy metabolism and development of early mammalian embryos. Theriogenology, 37: 75-93.

Rieger D, Loskutoff NM, Betteridge KJ (1992). Developmentally related changes in the metabolism of glucose and glutamine by cattle embryos produced and co-cultured in 
vitro. Journal of Reproduction and Fertility, 95: 585-595.

Rivera RM; Hansen PJ (2001). Development of cultured bovine embryos after exposure to high temperatures in the physiological range. Reproduction, 121: 107-115.

Sakatani M, Kobayashi S, Takahashi M (2004). Effects of heat shock on in vitro development and intracellular oxidative state of bovine preimplantation embryos. Molecular Reproduction and Development, 67: 77-82.

Sartori R, Sartor-Bergfelt R, Mertens SA, Guenther JN, Parrish JJ, Wiltbank MC (2002). Fertilization and early embryonic development in heifers and lactating cows in summer and lactating and dry cows in winter. Journal of Dairy Science, 85: 28032812.

Sonna LA, Fujita J, Gaffin SL, Lilly CM. 2002. Invited review: Effects of heat and cold stress on mammalian gene expression. Journal of Applied Physiology, 92: 17251742.

Sugiyama S, McGowan M, Phillips N, Kafi M, Young $M$ (2007). Effects of increased ambient temperature during IVM and/or IVF on the in vitro development of bovine zygotes. Reproduction of Domestic Animals, 42: 271-274.

Taylor DM, Handyside AH, Ray PF, Dibb NJ, Winston RM, Ao A (2001). Quantitative measurement of transcript levels throughout human preimplantation development: analysis of hypoxanthine phosphoribosyl transferase. Molecular Human Reproduction, 7: 147-154.

Tian WN, Braunstein LD, Pang J, Stuhlmeier KM, Xi QC, Tian X, Stanton RC (1998). Importance of glucose-6-phosphate dehydrogenase activity for cell growth. Journal of Biological Chemistry, 273:
10609- 10617.

Tiffin GJ, Rieger D, Betteridge KJ, Yadav BR, King WA (1991). Glucose and glutamine metabolism in pre-attachment cattle embryos in relation to sex and stage of development. Journal of Reproduction and Fertility, 93 125-132.

Williams TJ (1986). A technique for sexing mouse embryos by a visual colorimetric assay of the $\mathrm{X}$-linked enzyme, glucose 6 -phosphate dehydrogenase. Theriogenology, 25: 733739.

Wrenzycki C, Herrmann D, Carnwath JW, Niemann H (1999). Alterations in the relative abundance of gene transcripts in preimplantation bovine embryos cultured in medium supplemented with either serum or PVA. Molecular Reproduction and Development, 53: 8-18.

Wrenzycki C, Herrmann D, Keskintepe L, Martins A, Sirisathien S, Brackett B, Niemann H (2001). Effects of culture system and protein supplementation on mRNA expression in pre-implantation bovine embryos. Human Reproduction, 16: 893901.

Wrenzycki C, Lucas-Hahn A, Herrmann D, Lemme E, Korsawe K, Niemann H (2002). In vitro production and nuclear transfer affect dosage compensation of the $\mathrm{X}$-linked gene transcripts G6PD, PGK, and Xist in preimplantation bovine embryos. Biology of Reproduction, 66. 127-134.

Wutz A, Gribnau J (2007). X inactivation Xplained. Current Opinion in Genetics and Development, 17: 387-393.

Yang HW, Hwang KJ, Kwon HC, Kim HS, Choi KW, Oh KS (1998). Detection of reactive oxygen species (ROS) and apoptosis in human fragmented embryos. Human Reproduction, 13: 998-1002. 